\title{
The Other Side of the CAFA Effect: An Empirical Analysis of Class Action Activity in the Oklahoma State Courts
}

\author{
Steven S. Gensler
}

\section{INTRODUCTION}

When Congress passed the Class Action Fairness Act of 2005 (CAFA), it stated that it was seeking to provide a fair, federal forum for cases of national import and interest. ${ }^{1}$ In the section of CAFA titled "Findings and Purposes," Congress claimed to be reacting to abusive state-court class action practices that yielded unfair results, undermined public respect for the judicial system, undermined interstate commerce and the national judicial system, and usurped the legislative prerogatives of other states. ${ }^{2}$ CAFA addresses those problems by providing expansive diversity-based original jurisdiction over multistate class actions and by providing for ready removal to federal court when such cases are filed in state court.

CAFA represents reform by resettlement. Rather than attempting to regulate what was happening in the state courts, Congress chose to reform class action practice by shifting class actions from the state-court dockets, where abuse was allegedly rampant, to the federal-court

Welcome D. \& W. DeVier Pierson Professor, University of Oklahoma College of Law. I want to thank the University of Kansas School of Law and the Kansas Law Review for hosting this symposium and inviting me to participate. I also want to thank the University of Oklahoma College of Law for supporting this research project and Richard Sutterfield at Kellpro, Inc. for his assistance in obtaining data from the sixty-four counties that utilize the Oklahoma District Court Records electronic docket system.

General thanks cannot begin to describe my gratitude and indebtedness to Isaac Ellis and Meredith Walck, my student research assistants, who did most of the really tedious work gathering, filtering, and coding the data. This acknowledgement is small recompense for their labors, and I hope that someday they will find it in their hearts to forgive me. Finally, much of the credit (and none of the blame) for this project belongs to Emery Lee and Tom Willging at the Federal Judicial Center, who helped greatly with the design of the study and provided me with access to their federalcourt data.

1. See infra notes $41-46$ and accompanying text. See generally Class Action Fairness Act of 2005, Pub. L. No. 109-2, § 2, 119 Stat. 4, 4-5 (codified in scattered sections of 28 U.S.C.) (Findings and Purposes).

2. Class Action Fairness Act $\S 2$. 
dockets, where abuse was thought less prevalent and where Congress could more directly exercise regulatory authority in the future. This docket transfer from state court to federal court is referred to as the "CAFA effect." While people debated about how pronounced the CAFA effect would be, ${ }^{4}$ there was little doubt that it would occur.

CAFA took effect on February 18, 2005, over four years ago. ${ }^{5}$ What has happened since then? Has CAFA in fact shifted nationwide state-law class actions from state court to federal court? If so, how large has the shift been? Has the shift been uniform across the states and the federal courts in those states?

Some of the data needed to try to answer those questions are being collected from the federal-court system. After CAFA took effect, the Advisory Committee on Civil Rules asked the Federal Judicial Center (FJC) to study federal-court class action practice in the wake of CAFA. ${ }^{6}$ The FJC began collecting data in 2005 and has been presenting interim reports to the Advisory Committee since $2006 .^{7}$ One of the interim findings has been that there has been an increase in the number of statelaw class actions filed in federal court since CAFA took effect on February $18,2005 .^{8}$ When presenting these findings, however, the FJC researchers have been quick to disclaim any conclusion that CAFA has shifted state-law class actions from state court to federal court. That would require knowing whether state-court class action filings have experienced a corresponding decrease. ${ }^{9}$

Getting corresponding state-court data is no small task. As of this date, there is no centralized general database of state-court class action data. Thus, the only way to get corresponding state-court data is for researchers to collect and analyze those data on a state-by-state basis. Even then, there is no assurance that any particular state will have

3. Emery G. Lee III \& Thomas E. Willging, The Impact of the Class Action Fairness Act on the Federal Courts: An Empirical Analysis of Filings and Removals, 156 U. PA. L. REV. 1723, 1748 (2008).

4. See id. at 1740-42 (discussing the range of predictions).

5. Class Action Fairness Act $\S 9$.

6. EMERY G. Lee III \& ThOMAS E. Willging, The Impact of the Class Action Fairness ACT OF 2005 ON THE FEDERAL COURTS: FOURTH INTERIM REPORT TO THE JUDICIAL CONFERENCE ADVISORY COMMITTEE ON CIVIL RULES 1 (2008), http://www.fjc.gov/public/pdf.nsf/lookup /cafa0408.pdf/\$file/cafa0408.pdf.

7. The FJC's interim publications are available at the FJC's website. Federal Judicial Center, http://www.fjc.gov/public/home.nsf.

8. See LEE \& WiLLGING, supra note 6, at 5-7.

9. Lee \& Willging, supra note 3 , at 1748 ("To demonstrate a CAFA effect on diversity cases conclusively, one would need accurate information about class action activity in the state courts comparable to that collected by the Center about class action activity in the federal courts."). 
reliable or accessible records in this area. ${ }^{10}$ The result is that collecting parallel state-court data likely will be a hit-and-miss proposition at best.

Some data do exist. A limited study of class action activity in Madison County, Illinois - a jurisdiction regularly cited by class action critics as a class action hellhole - showed a very substantial drop in class action activity after CAFA. ${ }^{11}$ A much more comprehensive study of class action activity is underway in California. In collaboration with the University of California Hastings College of Law, the Office of Court Research (OCR) of the California Administrative Office of the Court initiated a project to study class actions in the California state courts. ${ }^{12}$ The OCR study currently has data from 2000 through mid-2006, with plans to update those data through 2008. ${ }^{13}$ The OCR study of California class actions is hugely important. California is the largest state in the union (by population ${ }^{14}$ ) and has the largest economy of the states. ${ }^{15}$ It also has one of the largest court systems. ${ }^{16}$ If we could collect data from

10. Stephen B. Burbank, The Class Action Fairness Act of 2005 in Historical Context: A Preliminary View, 156 U. PA. L. REV. 1439, 1500 (2008) ("I am aware of no reliable data, historical or current, concerning state court class actions, and I doubt that reliable data exist for most states."); Lee \& Willging, supra note 3, at 1763 ("The lack of state court data on class actions stems from multiple sources, including the lack of necessary resources to collect the data in the state systems and the lack of common computerized case management systems.").

11. See Howard M. Erichson, CAFA's Impact on Class Action Lawyers, 156 U. PA. L. REV. 1593, 1609-10 (2008) (noting that Madison County's judiciary also underwent reforms during this period but stating that a connection between CAFA and the drop in filings was strongly suggested).

12. See Hilary Hehman, Findings of the Study of California Class Action LITIGATION, 2000-2006: FIRST INTERIM REPORT 1 (2009), http://www.courtinfo.ca.gov/reference /documents/class action-lit-study.pdf.

13. See Administrative Office of the Courts, Fact SheEt: Study of California Class ACTION LITIGATION 3 (2010), http://www.courtinfo.ca.gov/reference/documents/factsheets /sccal.pdf.

14. U.S. Census Bureau, State Rankings-Statistical Abstract of the United States: Resident Population—July 2008, http://www.census.gov/compendia/statab/2010/ranks/rank01.html (last visited Feb. 13, 2010) [hereinafter Resident Population Rankings] (resident population ranking as of July 2008).

15. U.S. Census Bureau, State Rankings-Statistical Abstract of the United States: Gross Domestic Product by State in Current Dollars, 2007, http://www.census.gov/compendia /statab/2010/ranks/rank28.html (last visited Feb. 13, 2010) [hereinafter Gross Domestic Product Rankings] (gross domestic product by state in current dollars for 2007).

16. The National Center for State Courts (NCSC) compiles annual reports on the work of the state courts. See Court Statistics Project, Examining the Work of State Courts, 2007: A National Perspective from the Court Statistics Project 5 (2008), http://www.ncsconline .org/D Research/csp/2007B files/Examining Final - 2007 - 1 - Whole; COURT STATISTICs ProjECT, State Court Caseload Statistics, 2007: Supplement to Examining the Work of State COURTS, 2007, at 6 (2008), http://www.ncsconline.org/D Research/csp/2007 files/State Court Caseload Statistics 2007.pdf. Because state court systems vary in their structure and in the ways in which they track docket statistics and workloads, it would be difficult to unequivocally say that any one state had the largest court system. Nonetheless, even a casual reading of the caseload statistics assembled by the NCSC will confirm that California has one of the largest state court systems both in terms of number of courts and total caseload. 
only one state, it would not be inappropriate to select California. That being said, the qualities that make California so significant also make it atypical of most states. Whatever impact CAFA has had on class action practice in California, it would be dangerous at best to extrapolate that impact to the other forty-nine states.

This study offers a look at the impact of CAFA on a very different state. Oklahoma lies in the heart of the heartland, and not just in terms of geography. It is the twenty-eighth largest state in terms of population ${ }^{17}$ and the eighteenth largest state in terms of area. ${ }^{18}$ The Oklahoma economy, while diverse overall, has significant concentrations in agriculture and natural resources. ${ }^{19}$ Oklahoma ranks twenty-ninth among the states in terms of gross state product. ${ }^{20}$ In most senses of the term, one fairly can describe Oklahoma as a middle state. It certainly offers a contrast to California.

There is another reason why Oklahoma makes for an interesting case study. During the 2000s, Oklahoma gained a reputation as being a friendly forum for class actions. Beginning in 2000, the Texas Supreme Court issued a series of decisions that drastically curtailed class certification in the Texas state courts. ${ }^{21}$ Sensing the need for greener pastures, class action lawyers followed the first leg of the Chisholm Trail $^{22}$ and crossed the Red River into Oklahoma. ${ }^{23}$ Once there, they found a much more welcoming class action environment. For example, the Texas courts required trial plans and could certify a class only if the

17. Resident Population Rankings, supra note 14

18. See The US50, Listing of the 50 States Ranked by Size in Square Miles, http:// www.theus50.com/area.php (last visited Feb. 9, 2010).

19. See Oklahoma Dep't of Commerce, Economic \& Business Data, http://www.okcommerce .gov/index.php?option=content\&task=view\&id=310\&Itemid=

391 (follow "Gross State Product" hyperlink; then follow "1997 to 2008 BEA Oklahoma Gross Domestic Product by Industry” hyperlink).

20. Gross Domestic Product Rankings, supra note 15.

21. See, e.g., Compaq Computer Corp. v. Lapray, 135 S.W.3d 657, 669-70 (Tex. 2004) (requiring trial courts to conduct a rigorous choice of law analysis before determining predominance); Sw. Ref. Co. v. Bernal, 22 S.W.3d 425, 435 (Tex. 2000) (requiring trial courts to rigorously analyze the certification requirements and rejecting the "certify now, worry later" approach). See generally Alistair B. Dawson \& Geoff A. Gannaway, In Memoriam: Texas Class Actions, 72 TEX. B.J. 366, 368 (2009) ("The most significant deterrent for Texas class actions has undoubtedly been the relentless tightening of certification requirements by the Texas Supreme Court.").

22. The Chisholm Trail stretched from Texas to Kansas. Along the Chisholm Trail, http://www.thechisholmtrail.com/ (last visited Feb. 14, 2010). Millions of head of cattle were rounded up in Texas and driven north, through Oklahoma, to the stockyards of Kansas to be sold and shipped to Chicago or other points east. Id.

23. See Dawson \& Gannaway, supra note 21, at 373 ("Cases that used to be filed in Texas are now being filed in states such as Oklahoma and Arkansas.”). 
plaintiff could presently show that it met all of the criteria for certification. $^{24}$ In contrast, the Oklahoma Supreme Court did not require trial plans and even directed the Oklahoma trial courts to err on the side of certification under the view that the trial court could always decertify later. $^{25}$

Class action lawyers also found more favorable choice-of-law rules in Oklahoma. In several decisions in the early 2000s, the Texas Supreme Court erected choice-of-law obstacles to certification by (1) holding that trial courts could not find predominance without conducting a proper choice-of-law analysis to determine whether the claims would be subject to one law or the law of multiple states; ${ }^{26}$ and (2) interpreting Texas's version of the Restatement (Second) of Conflict of Laws to pick, for each class member, the law of the class member's home state. ${ }^{27}$ In contrast, the Oklahoma Supreme Court construed Oklahoma's version of the Restatement (Second) of Conflict of Laws as selecting a single law-the law of the defendant's home state - to govern the warranty claims of all class members in a nationwide warranty class action. ${ }^{28}$ In so doing, the Oklahoma Supreme Court greatly enhanced the odds of getting class certification by eliminating the potentially fatal obstacle of having to apply multiple laws. ${ }^{29}$

All of these factors converged in the notorious Compaq v. Lapray litigation. That case, originally filed in Texas state court, sought class certification of a national class of computer purchasers and asserted claims for breach of warranty. ${ }^{30}$ The trial court granted class certification and in 2002 the Court of Appeals of Texas affirmed. ${ }^{31}$ While the certification order in Lapray was on appeal to the Texas Supreme Court, the class lawyers protectively filed a parallel suit in Cleveland County, Oklahoma, in 2003, where it proceeded under the

24. State Farm Mut. Auto. Ins. Co. v. Lopez, 156 S.W.3d 550, 556 (Tex. 2004) (trial plan required for every certification order); Sw. Ref. Co., 22 S.W.3d at 435 (trial plan assures that the trial court has fulfilled its duty to rigorously analyze all certification requirements).

25. Perry v. Meek, 618 P.2d 934, 940 (Okla. 1980) ("The pragmatically correct action, in the face of a close question as to certification, has been said to sustain certification because if it develops later during the course of the trial that the order is ill-advised, the order is always (prior to judgment on the merits,) subject to modification."); see also Masquat v. DaimlerChrysler Corp., 195 P.3d 48, 53 (Okla. 2008) (same (quoting Perry, 618 P.2d at 940)); Harvell v. Goodyear Tire \& Rubber Co., 164 P.3d 1028, 1032 (Okla. 2006) ("[I]n the face of a close question as to certification, the Court has held that the pragmatic action is to sustain certification.").

26. Henry Schein, Inc. v. Stromboe, 102 S.W.3d 675, 698 (Tex. 2002).

27. Compaq Computer Corp. v. Lapray, 135 S.W.3d 657, 681 (Tex. 2004).

28. Ysbrand v. DaimlerChrysler Corp., 81 P.3d 618, 625-26 (Okla. 2003).

29. See id.

30. Lapray, 135 S.W.3d at 661-62.

31. Compaq Computer Corp. v. Lapray, 79 S.W.3d 779, 784 (Tex. App. 2002). 
name of Grider v. Compaq Computer Corp. ${ }^{32}$ In May 2004, the Texas Supreme Court reversed the certification order in Lapray in part on its finding that Texas law would not apply to all class members. ${ }^{33}$ The following year, in September 2005, the Cleveland County court found that Texas law would apply to all class members under Oklahoma choice-of-law rules and certified essentially the same national warranty class that the Texas Supreme Court had rejected. In 2008, the Cleveland County court approved a class-wide settlement with a stated face value of $\$ 630$ million but that mostly consisted of coupons. ${ }^{34}$ The only people to receive hard cash in the settlement were the class lawyers; they received $\$ 40$ million in attorney's fees plus almost $\$ 8$ million for costs and expenses. ${ }^{35}$

The class action conditions in Oklahoma during this period did not go unnoticed. It was at this time that the American Tort Reform Association (ATRA) began publishing its annual report of so-called "judicial hellholes." In 2004, Oklahoma made the "Dishonorable Mention" list with the comment that "plaintiffs' lawyers from surrounding states, particularly Texas, stand ready at the Oklahoma border. Some have already begun to stake a claim on its courthouses." ${ }^{\prime 36}$ In an amicus brief in support of DaimlerChrysler's petition for a writ of certiorari, the United States Chamber of Commerce singled out certain states as being havens for abusive class action practices and concluded that "Oklahoma will undoubtedly draw lawyers from across the nation who are attempting to certify nationwide classes." 37 Oklahoma's reputation even extended to Congress. A Senate Report accompanying

32. See generally Linda Silberman, The Role of Choice of Law in National Class Actions, 156 U. PA. L. REV. 2001, 2015-18 (2008) (describing in particular how the lawyers who had filed the well-known Compaq Computer Corp. v. Lapray suit in Texas later filed essentially the same action in Oklahoma under the name Grider v. Compaq Computer Corp.). A second, parallel suit against Hewlett-Packard Co. (which purchased Compaq) was also filed in Cleveland County and captioned Barrett v. Hewlett-Packard Co., CJ-2003-967 (Cleveland County, Oklahoma). The Grider and Barrett cases were consolidated for certification and settlement on December 11, 2007.

33. Lapray, 135 S.W.3d at 681

34. Settlement Agreement and Release, Barrett v. Hewlett-Packard Co., No. CJ-2003-967 (Okla. Dist. Ct. Dec. 11, 2007), http://www.oscn.net/applications/oscn/getcaseinformation.asp? submitted $=$ true \&number $=$ CJ-2003-967\&db $=$ Cleveland \&viewtype $=$ oscn.

35. Order granting final approval to Class Action Settlement and Final Judgment at 2, 5, Barrett v. Hewlett-Packard Co., No. CJ-2003-967 (Okla. Dist. Ct. May 9, 2008), http://www.oscn.net /applications/oscn/getcaseinformation.asp?submitted=true\&number $=$ CJ-2003$967 \& \mathrm{db}=$ Cleveland \&viewtype $=$ oscn.

36. AM. TORT REFORM ASs'N, JUdiCiAl HellhOles 2004, 33, http://www.atra.org/reports /hellholes/2004/hellholes2004.pdf.

37. Brief of the Chamber of Commerce of the United States et al. as Amici Curiae in Support of Petitioner at 12, DaimlerChrysler Corp. v. Ysbrand, 542 U.S. 937 (2004) (No. 03-1342), 2004 WL 1174634 , at $* 12$. 
CAFA referred specifically to Ysbrand in its discussion of how states can undermine basic principles of federalism by applying the law of a single state to all class members of a nationwide class action. ${ }^{38}$

By reciting this history, I do not mean to take any position here on the tort-reform debate generally. Nor do I mean to make any normative judgments about the state of Oklahoma's class action practice during this period, ${ }^{39}$ though I did express after Ysbrand that Oklahoma's class action environment was likely to attract additional national class action activity. ${ }^{40}$ My point here is simply this: to the extent CAFA was a response to alleged forum-shopping in the national class action market, then it is particularly apt to look at the impact of CAFA on Oklahoma as a state that was developing a reputation as one of the preferred forums.

With this background in place, I now turn to the body of the Article. It proceeds in two Parts. Part II briefly discusses the purpose and design of CAFA. Part II shows how the expansive jurisdiction and removal provisions of CAFA sweep in most multistate class actions of any significant size, creating the potential for a massive transfer of national state-law class actions from state court to federal court. Part II further shows, in contrast, that while CAFA contains exceptions for "in-state" class actions, they are very narrow and leave little room for lawyers to structure state-specific class actions that would fall outside CAFA's removal provisions.

Part III presents findings from my empirical study of Oklahoma class actions. The study found a significant reduction in class action filings in the Oklahoma state courts post-CAFA. However, the Oklahoma federal courts experienced a similar reduction in class action filings during this same period. These data suggest that CAFA has not led to a transfer of class actions from Oklahoma state court to the federal courts in Oklahoma. But national federal-court data from the FJC show an overall

38. S. REP. NO. 109-14, at 25 \& n.111 (2005).

39. Oklahoma's status as a class friendly forum may already be over. Effective November 1, 2009, Oklahoma's class action rule was amended as part of a comprehensive tort-reform bill. H.B. 1603 (Okla. 2009) (enacted). Among the reforms are a provision providing for de novo review of certification decisions, see OKLA. STAT. tit. $12 \S 2023(\mathrm{C})(2)(2009)$, a provision restricting the inclusion of out-of-state residents in a class without the defendant's consent, see OKLA. STAT. tit. 12 $\S 2023(\mathrm{D})(3)$, and a fee-award provision requiring that class lawyers who obtain coupons or other similar forms of compensation be paid in kind, see OKLA. STAT. tit. $12 \S 2023(\mathrm{G})(4)(\mathrm{f})$. Oklahoma's recent round of class action reform supports the view expressed by some that, over time, the problem of so-called "class action hellholes" will often be self-correcting. See Burbank, supra note 10, at 1522-23; Richard L. Marcus, Assessing CAFA's Stated Jurisdictional Policy, 156 U. PA. L. REV. 1765, 1767-68 (2008).

40. Steven S. Gensler, Civil Procedure: Class Certification and the Predominance Requirement Under Oklahoma Section 2023(B)(3), 56 OKLA. L. REV. 289, 326 (2003). 
increase in diversity class actions post-CAFA, with very large increases in certain circuits. Taken together, the data suggest that CAFA may have shifted class actions from state court to federal court generally, but not evenly, as plaintiffs bringing these new federal filings targeted what they perceived to be the more favorable federal districts and circuits. Consider national warranty class actions like Ysbrand and Grider. PreCAFA they were brought in Oklahoma state court. The CAFA effect for cases like these may be that they are now brought in federal courts in other parts of the country like the Third Circuit or the Ninth Circuit.

In addition to filing rates, my empirical study collected Oklahoma state-court data on class certification decisions and outcomes in certified cases. Part III provides interim findings on those issues as follows: (1) a motion to certify the case as a class action was made in approximately half of the cases; (2) when a motion to certify was made, it was granted over half of the time and seldom denied; and (3) when certification was granted, by far the most likely outcome was a settlement.

\section{The PuRPose AND DESIGN OF CAFA}

When Congress passed CAFA, it did so with a clearly stated purpose - to shift state-law class actions that were of nationwide or multistate scope from the state courts to the federal courts. ${ }^{41}$ In CAFA, Congress made legislative findings about the state of class action practice in the United States. It began with a conditional endorsement of class actions, stating that class actions "are an important and valuable part of the legal system when they permit the fair and efficient resolution of legitimate claims." 42 But the clear thrust of the findings was to lay a foundation for reform by attacking what they characterized as "abuses of the class action device," including situations where class actions result in large fees for lawyers while providing no real benefit to the class members. ${ }^{43}$ According to Congress, these abuses-which Congress implicitly and indirectly laid on the doorstep of the state courts-were

41. Class Action Fairness Act of 2005, Pub. L. No. 109-2, § 2(b)(2), 119 Stat. 4, 5 (codified in scattered sections of 28 U.S.C.). While some CAFA critics have denounced the articulated policy justification, or have argued that CAFA fails to serve those policies, it is surely true that Congress could validly use jurisdictional reform to curb the abuses that allegedly were occurring in nationwide class actions pending in certain state courts. See Marcus, supra note 39, at 1768. As CAFA critic Professor Burbank has noted, "[a] reasonable member of Congress in 2005 could have concluded that there was a need to change the balance of power in forum selection for class litigation between plaintiffs and defendants." Stephen B. Burbank, The Class Action Fairness Act of 2005 and Federalism-Precis, 35 W. ST. U. L. REV. 11, 11 (2007).

42. Class Action Fairness Act $\S 2(a)(1)$.

43. $I d . \S 2(a)(3)$. 
undermining the national judicial system and harming the national economy. ${ }^{44}$ Congress's findings also reflected the view that class action lawyers were manipulating the system, imposing extraordinary costs on defendants while providing no real benefit to the class members who were allegedly harmed. ${ }^{45}$ Thus, the declared purpose of CAFA was to restore fairness to the resolution of national class actions "by providing for Federal court consideration of interstate cases of national importance under diversity jurisdiction." 46

Whether or not Congress's view of the situation was correct or sincere, it is certainly clear that the jurisdictional framework in place before CAFA allowed for the development of a national class action market and for the possibility of state-to-state forum shopping. As a function of personal jurisdiction, it was a truly national market. In most nationwide class actions, the national nature of the conduct, the availability of general contacts-based jurisdiction, and the Supreme Court's ruling in Phillips Petroleum Co. v. Shutts regarding personal jurisdiction over absent class members combined to enable the putative named plaintiff and her lawyer to bring suit in just about any state in the country. ${ }^{47}$ And under the diversity-jurisdiction rules in place at the time, plaintiffs had little trouble crafting their lawsuits in ways that precluded their removal to federal court. ${ }^{48}$ The end result, according to the critics and some judges, was that plaintiffs' class action lawyers were free to shop across the country for the anomalous forum that would certify the class or approve an unfair settlement. ${ }^{49}$

Rather than attempt to regulate state-court class action practices directly, ${ }^{50}$ Congress chose to address the problem indirectly. It took

44. Id. § 2(a)(4).

45. See Erichson, supra note 11, at 1596-1602 (cataloguing how class action lawyers were described by members of Congress and portrayed in the media).

46. Class Action Fairness Act $\S 2(b)(2)$.

47. Phillips Petroleum Co. v. Shutts, 472 U.S. 797, 811-12 (1985); Burbank, supra note 10, at 1521 (characterizing this combination as creating "exorbitant assertions of state court adjudicatory authority").

48. Burbank, supra note 10 , at $1450-52$ (discussing how the amount-in-controversy requirement and the plaintiff's ability to select a nondiverse class member as a named plaintiff served as obstacles to diversity-based removal); Marcus, supra note 39, at 1770-76 (discussing the pre-CAFA jurisdictional framework and concluding that "there is little to favor the pre-CAFA jurisdictional treatment of class actions except that it was already there").

49. John H. Beisner \& Jessica Davidson Miller, They're Making a Federal Case Out of It . . In State Court, 25 HARV. J.L. \& PUB. POL'Y 143, 155, 167 (2001); Samuel Issacharoff \& Richard A. Nagareda, Class Settlements Under Attack, 156 U. PA. L. ReV. 1649, 1655-56, 1660-66 (2008). Moreover, failure in one forum was not fatal because, as Judge Easterbrook vividly put it, the class lawyers could try again in other states and "[a] single positive trumps all the negatives." In re Bridgestone/Firestone, Inc., Tires Prods. Liab. Litig., 333 F.3d 763, 766-67 (7th Cir. 2003).

50. For example, Congress could have addressed the choice-of-law problem by adopting a 
national state-law cases away from the state courts and put them in the hands of federal judges who presumably would be less likely to allow abuse. $^{51}$ As a side benefit, putting these cases in the hands of federal judges would give Congress a much clearer path to legislatively address class action abuse in the event abusive practices persisted or developed in federal court. ${ }^{52}$

In its design, CAFA is crafted to cast a remarkably wide net. CAFA starts by extending jurisdiction to all class actions in which there is minimal diversity, an aggregate amount in controversy of $\$ 5$ million, and at least 100 class members. ${ }^{53}$ Any multistate class action would necessarily meet the first criteria. And I think it is fair to conclude that the vast majority of multistate class actions would meet the last two criteria. ${ }^{54}$ While CAFA jurisdiction is concurrent with state-court jurisdiction-i.e., plaintiffs may still choose to file qualifying suits in state court - CAFA contains generous removal provisions to ensure that the federal courthouse doors are wide open for qualifying suits originally filed in state court. In particular, CAFA's removal provisions identify

national rule for choice of law in national class actions. See Silberman, supra note 32, at 2005. Also, Congress could have addressed the problem of overlapping class actions or repeat efforts at certification by amending the Anti-Injunction Act. Burbank, supra note 10, at 1539.

51. Erichson, supra note 11, at 1597 (noting that the principal animating factor was distrust of lawyers, but that the jurisdictional shift resulted from the belief that state-court judges could not be trusted to monitor and restrain the untrustworthy lawyers); Samuel Issacharoff \& Catherine M. Sharkey, Backdoor Federalization, 53 UCLA L. REV. 1353, 1416 (2006) ("The congressional response was to open up the federal forum as a bulwark against improper or opportunistic state-court oversight of the national market."); Tobias Barrington Wolff, Federal Jurisdiction and Due Process in the Era of the Nationwide Class Action, 156 U. PA. L. REV. 2035, 2037 (2008) (CAFA reflects Congress's "belief that federal courts will apply different and more restrained standards to the administration of class actions than will state courts, thus providing greater confidence that the interests of parties on both sides of the dispute will be protected from abuse.").

52. For example, Congress directly regulated federal securities class actions with the enactment of the Private Securities Litigation Reform Act of 1995 ("PSLRA"), Pub. L. No. 104-67, 109 Stat. 737 (1995) (codified at 15 U.S.C. $\$ \$ 77 \mathrm{z}-1$ and $78 \mathrm{u}-4$ (2006)).

53. 28 U.S.C. $§ 1332(\mathrm{~d})(2)$ (2006) (minimal diversity); id. $\S 1332(\mathrm{~d})(5)(\mathrm{B})$ (100 class members); id. $\S 1332(\mathrm{~d})(6)$ (aggregate amount in controversy). CAFA also extends jurisdiction to so-called "mass actions." Id. § 1332(d)(11).

54. A 2003 empirical study by the FJC indicated that most class actions have well over 100 class members. Lee \& Willging, supra note 3, at 1735 . While that study also found that recoveries and settlements frequently are less than $\$ 5$ million, id. at 1734 , the amount in controversy is measured ex ante and, at least in original filings, is met if a recovery above the jurisdictional amount is possible. St. Paul Mercury Indem. Co. v. Red Cab Co., 303 U.S. 283, 289 (1938) ("legal certainty" test). Determining the amount in controversy is a more difficult task in removed cases, and the circuit law varies. Some circuits apply the legal certainty test to removed actions as well. McPhail v. Deere \& Co., 529 F.3d 947, 954 (10th Cir. 2008). But other circuits apply tests that leave room for plaintiffs to manipulate their claims for relief in a way that might permit them to circumvent the jurisdictional amount and thereby frustrate removal. Lowery v. Ala. Power Co., 483 F.3d 1184, 1207-15 (11th Cir. 2007) (finding that the court may consider only the removal papers and not extrinsic evidence). 
the three major obstacles to removal in general diversity-jurisdiction cases and make them inapplicable in CAFA cases. ${ }^{55}$ In sum, CAFA's basic jurisdictional provisions make it very likely that any significant multistate class action can be either filed in or removed to federal court.

Despite casting a wide net generally, CAFA does contain a small set of exceptions. Most important for our purposes are two exceptions designed to preserve the role of state courts over class actions that are genuinely in-state matters. ${ }^{56}$ First, CAFA contains an exception generally known as the "home state" exception for cases in which the principal defendants and two-thirds of the class members are citizens of the state in which the action is filed. ${ }^{57}$ Second, CAFA contains an exception generally known as the "local controversy" exception. ${ }^{58}$ It too requires that two-thirds of the class members be citizens of the state in which the action is filed, but expands on the "home state" exception by conferring jurisdiction if any significant defendant is a citizen of that state and the injuries and conduct in question are local to that state. ${ }^{59}$ These exceptions have been justly criticized for being uncertain and cumbersome structures that require litigants and courts to expend energy and resources on identifying the proper forum rather than resolving the merits. ${ }^{60}$ That being said, the most important quality of these carve-outs is their limited scope.

Only a small subset of the claims contained in a truly nationwide class action can ever fit within these in-state class action carve-outs. ${ }^{61}$ Most critically, CAFA does not allow lawyers to simply break up their

55. 28 U.S.C. $§ 1453$ (b) (stating that CAFA removals are not subject to the one-year cap under $\S 1446$ (b), are allowed even if there is a home-state defendant, and do not require the consent of all defendants).

56. For a discussion of U.S. Judicial Conference policy on CAFA and the policy position that class action reform should leave truly in-state class actions in state court, see Lee \& Willging, supra note 3, at 1725-33 (chronicling the evolution and formation of U.S. Judicial Conference policy on expanded federal jurisdiction over multistate class actions).

57. 28 U.S.C. $\S 1332(\mathrm{~d})(4)(\mathrm{B})$.

58. Id. $\S 1332(\mathrm{~d})(4)(\mathrm{A})$.

59. Id. (also requiring no other class action on those facts to have been brought against any of the defendants during the previous three years). CAFA also contains a discretionary carve-out with a dizzying array of factors in cases where more than one-third but less than two-thirds of the class members are citizens of the state where the case is filed. See id. $\S 1332(\mathrm{~d})(3)$.

60. Kevin M. Clermont \& Theodore Eisenberg, CAFA Judicata: A Tale of Waste and Politics, 156 U. PA. L. REV. 1553, 1554-58 (2008) (describing carve-outs for in-state class actions as "bewilderingly complicated" and asserting that CAFA has already generated a great deal of socially wasteful litigation over its scope and application).

61. Jay Tidmarsh, Finding Room for State Class Actions in a Post-CAFA World: The Case of the Counterclaim Class Action, 35 W. ST. U. L. REV. 193, 195 (2007) ("Although CAFA was crafted to keep small and predominantly local state-law class actions in state court, few class actions can take advantage of these limitations."). 
national class actions into state-by-state class actions to be litigated in state court. The "home state" and the "local controversy" exceptions apply only when a largely or predominantly in-state class sues an in-state defendant.

Consider the fate of a national class action like Ysbrand $v$. DaimlerChrysler Corp. ${ }^{62}$ under the CAFA scheme. With class members from all over the country and tens of millions of dollars of claimed damages, it would clearly qualify for CAFA jurisdiction. ${ }^{63}$ Moreover, the plaintiffs' lawyers could not circumvent CAFA simply by breaking it up into fifty separate class actions, one brought in each state by a class of citizens of that state. It is true that a "Michigan" class suing in Michigan would fall within the in-state carve-outs because the class members and the defendant would be citizens of the filing state. But any other statebased class - e.g., an "Oklahoma" class in Oklahoma or a "California" class in California-would fall outside the CAFA exceptions because DaimlerChrysler is not a citizen of those states. Thus, while CAFA preserves state-court jurisdiction when a defendant is sued in its own state by a local class, it opens up federal-court jurisdiction any time the defendant is sued in other states or by classes of citizens of other states. ${ }^{64}$

Despite the breadth of its jurisdictional coverage, CAFA still has one big hole. Like general diversity jurisdiction, CAFA jurisdiction is concurrent with state-court jurisdiction and not exclusive of it. In other words, it permits original filing and removal but requires neither. The significance of not closing off access to the state courts is that the named plaintiffs and the defendants can still take advantage of state courts that will approve abusive settlements. ${ }^{65}$ How? That's easy. If the plaintiff files a nationwide class action in the desired state and the defendant foregoes removal, then the state-court judge will be the one to determine certification and approve any class-wide settlement. A provision that would have granted a removal option to absent class members would

62. 81 P.3d 618, 625-26 (Okla. 2003).

63. See id. at 622 .

64. Professor Burbank specifically criticized Congress for failing to preserve a state-court forum for "a class action brought on behalf solely of the citizens of that state, alleging injuries sustained in the state as a result of the in-state activities of an out-of-state corporation doing substantial business in the state." Burbank, supra note 10, at 1527-28. See also Burbank, supra note 41, at 12 ("At the end of the day, CAFA's exceedingly narrow exceptions are revealed as another depressing example of legislative overreaching by those who invoke the virtues of federalism when it is convenient to do so.").

65. Burbank, supra note 10, at 1519; Issacharoff \& Nagareda, supra note 49, at 1666-67; Wolff, supra note 51, at 2039-43. 
have offered them some protection against collusive deals, but it was dropped. ${ }^{66}$

In summary, the structure of CAFA yields three general governing jurisdictional principles:

(1) Virtually all of the nationwide class actions previously filed in state court now can be originally filed in or removed to federal court.

(2) CAFA's carve-outs for in-state class actions are very narrow and are effectively limited to situations where an in-state class sues an instate defendant.

(3) Because CAFA jurisdiction is concurrent with state-court jurisdiction, plaintiffs still can file their nationwide class actions in state court, and nothing in CAFA obligates defendants to remove those cases to federal court.

Using the principles identified above as a guide, the following questions emerge about the impact of CAFA on Oklahoma state-court class action practice:

(1) Has CAFA affected the number of class action filings in Oklahoma?

(2) Has CAFA affected the number of removals from Oklahoma state court to federal court?

(3) As to the cases filed in Oklahoma state court and not removed, were they cases that fell outside CAFA jurisdiction or were they cases that the plaintiffs chose to file in state court and that the defendants chose not to remove?

(4) If there are cases that could have been filed in or removed to federal court but were not, does anything suggest whether they were left in Oklahoma state court for the purpose of obtaining the types of allegedly abusive certifications and settlement approvals that Congress said CAFA was intended to prevent?

Using the data collected in my empirical study, I can present interim findings on the first and second questions. While the available data allow for some speculation about the third and fourth questions, definitive findings will have to await the collection of additional data.

66. Wolff, supra note 51, at 2043. 


\section{THE CAFA EFFECT IN OKLAHOMA}

In order to test the hypothesis that CAFA was moving national statelaw class actions from the state courts to federal court, I conducted an empirical study of class action activity in cases filed in Oklahoma state court from 2001 through 2008. As part of that process, I collected data on a range of issues including filings, removal, certification requests, and outcomes of certified cases. Subpart A describes the methodology I used. Subpart B presents my findings on filings and removal. Subpart C presents interim findings on the frequency and outcomes of certification requests and on the fate of certified cases.

\section{A. Research Design and Methodology}

The purpose of this empirical study was twofold. One purpose was to collect filing data that would parallel Phase One of the FJC's study. ${ }^{67}$ These data would facilitate analysis of whether CAFA was shifting class actions from state court to federal court. Another purpose, though, was to collect data on class action practice in Oklahoma generally, similar to Phase Two of the FJC's study of federal-court class actions. ${ }^{68}$ These data would provide a first peek into what was happening in class actions that were being litigated in Oklahoma state courts. ${ }^{69}$ I initially used a study period of January 2001 through June 2008. I later updated the study period to extend through December 2008. The final data set contains cases filed from 2001 through 2008.

The first step in the study was to identify the population of cases in which there was any class action activity. Because one of the purposes of the study was to provide companion data to the FJC's study of federalcourt class actions, I sought to replicate its process to the extent possible.

67. Phase One of the FJC's study collected filing and removal data. EMERY G. LEE III \& Thomas E. Willging, IMPACT OF the Class ACtion Fairness ACT ON THE FEDERAl COURTS: Preliminary Findings From Phase Two's PRE-CAFA SAMPLE OF Diversity Class ACTIONS 1 (2008), http://www.fjc.gov/public/pdf.nsf/lookup/cafa1108.pdf/\$file/cafa1108.pdf.

68. Phase Two of the FJC's study will attempt to measure CAFA's impact, if any, on the litigation activity and judicial rulings in federal-court class actions. $I d$. at 1.

69. I am aware of no other similar study of class action practice in Oklahoma. The only empirical analysis of Oklahoma class actions that I know of, to date, is found in a study addressing tort reform in Oklahoma. See Patricia W. Hatamyar, The Effect of "Tort Reform" on Tort Case Filings, 43 VAL. U. L. REV. 559, 582-85 (2009). Given the more general nature of that study, however, the data is rather limited; it reaches only the thirteen counties that maintain electronic dockets on the state's OCIS system, and it reports only whether a case was classified on the docket as a class action. Id. at 583. Analysis of the docket sheets to confirm whether the case actually involved class action activity and to determine the outcome was limited to one county. Id. 
The FJC's study is a docket study of cases filed during the study period. ${ }^{70}$ To identify its population, the FJC did three things: (1) it conducted an electronic search of the federal docket sheets to identify possible class actions; (2) it then conducted a visual review of the docket sheets identified to eliminate false positives; and, finally, (3) it crosschecked those results against other resources that might identify class action cases. ${ }^{71}$ For this study, I used the same techniques, adapted to fit the different resources available to me.

To identify the population of class action cases, my research team conducted term searches of the two electronic databases that serve the Oklahoma state courts. Thirteen Oklahoma counties, including all of the counties containing Oklahoma's largest metropolitan areas, maintain real-time court-docket information on the Oklahoma Court Information System (OCIS), hosted on the Oklahoma State Courts Network. ${ }^{72}$ We searched the docket sheets electronically for the following terms: "2023"; "class action"; "class certification"; "certify"; and "class" within 200 words of "settlement." We then inspected the docket sheet for each case to identify those cases with class action activity and to eliminate false positives. ${ }^{73}$

The other sixty-four counties in Oklahoma-mostly the smaller, rural counties - do not keep real-time dockets on the OCIS. Rather, they utilize a private company, Kellpro, Inc., to provide computerized docket services. $^{74}$ That system is called the On Demand Court Records (ODCR) system. ${ }^{75}$ While we could not obtain direct access to the ODCR system, we arranged for Kellpro staff to electronically search the docket sheets and case codes for all civil actions using the terms "2023" and "class action." Kellpro staff also searched the docket entries, which ODCR lists as string entries, for any string that contained the term "class" and any one of the following: "action"; "certify"; "certification"; or

70. LEE \& WILLGING, supra note 67 , at 3.

71. Id. at 17 .

72. See Dockets of Oklahoma Courts, http://www.oscn.net/applications/oscn/start.asp ?viewType=DOCKETS (last visited Feb. 3, 2010) (describing scope and content of the OCIS system).

73. Unlike the FJC's study, we did not eliminate "duplicative" class actions. Lee \& Willging, supra note 3 , at 1746 . In our data, situations in which the same class action was filed by multiple parties in the same county, or in which arguably the same class action was filed by the same or multiple parties in different counties, were isolated and rare. In those few situations where it occurred, I elected to count each case as filed.

74. See Kellpro Products and Services, http://kellpro.com/products/kcs/ (last visited Feb. 3, 2010) (listing Kellpro’s Court System services).

75. See On Demand Court Records, http://www.odcr.com/ (last visited Feb. 3, 2010) (entry portal to the ODCR system). 
"settlement."76 Kellpro's search excluded civil actions that were coded FD (Family and Domestic), JFP (Paternity), and PO (Protective Order). As with the OCIS search results, the research team then inspected the docket sheet for each case to identify those cases with class action activity. We then combined the data sets derived from the OCIS and the ODCR systems.

As a cross-check, we searched Westlaw's "Oklahoma Cases" database for all published cases that involved class action activity. We also searched the electronic database of unpublished Oklahoma Court of Civil Appeals decisions hosted by the Oklahoma Attorney General's Office. $^{77}$ We then cross-checked the OCIS and ODCR search results against these databases.

The process we used should have identified a very high percentage of the cases with class action activity, though I cannot say how great that percentage is. ${ }^{78}$ In particular, the process is likely to have identified nearly every case in which class action activity proceeded beyond an initial designation of a case as a class action or beyond the assertion of class allegations in the complaint. In other words, it seems unlikely that the process will have missed many cases in which a party actually sought certification, and even less likely that it would have missed cases in which the court resolved the dispute on a class-wide basis. ${ }^{79}$

76. Technical differences between the functionality of the OCIS docket sheets and the ODCR system required us to vary the search process and search terms slightly, though — we believe - in a way that may have increased false positives rather than false negatives in the ODCR data set. In other words, because we could not perfectly reproduce the OCIS search process on the ODCR system, we selected alternatives that we believed would be over-inclusive, relying on visual inspection to eliminate the larger number of false positives.

77. Oklahoma Public Research System, Attorney General Opinions Search, http://oklegal. onenet.net/agopinions.basic.html (last visited Feb. 3, 2010).

78. See Lee \& Willging, supra note 3, at 1745 . We did not replicate the FJC's process exactly. As discussed above, technical limitations of the OCIS and the ODCR system required that we modify the search process. In addition, unlike the FJC, we did not search for the term "class" by itself. Early testing of the search process revealed that it would have produced an unreasonable amount of false positives that, given the system limitations, we could not otherwise limit or control for and that we could not feasibly eliminate by individual case review. But early testing also failed to indicate that the search terms we did use were generating false negatives. Accordingly, I chose not to search for the term "class" by itself. That being said, that decision necessarily increases the chance that the study failed to locate some cases with a minimal but qualifying amount of class action activity.

79. In most of the cases where the court certified a class action and then approved a class-wide resolution, the docket sheet virtually lit up with search term hits. That being said, we did find a nonnegligible number of very short docket sheets with just a few search-term hits in cases where (1) the parties quickly sought certification and approval of a class-wide settlement, (2) nobody contested any aspect of certification or settlement approval, and (3) the judge conducted minimal certification or approval proceedings. In those circumstances, it is possible that the court could certify a class and approve a class-wide settlement and yet generate a docket with docket entries so few, so brief, or so nondescriptive that they do not contain any of our search terms. 
The data we collected do differ from the FJC's Phase One data in one material respect. The FJC was able to code its cases by nature-ofsuit (e.g., contracts, torts, "other fraud") based on the civil cover-sheet information provided by the plaintiff's attorney at the time of filing. That type of information was not directly available from the electronic docket sheets kept on OCIS or the ODCR system. While it is possible to determine nature-of-suit information from the petitions (complaints) filed in state court, the petitions are only sometimes available electronically on OCIS and are never available electronically on the ODCR system. We did not undertake to obtain hard copies of the petitions in all of the class action filings from all of the seventy-seven Oklahoma counties. Accordingly, I can only present aggregate filings data and cannot present data on nature-of-suit trends.

\section{B. Filings and Removals}

This section presents findings on the core question of this studywhether class action filings in Oklahoma state court dropped after CAFA took effect. Figure 1 presents a bar graph of all class action filings in the Oklahoma state courts during the eight-year study period from 2001 through 2008. Class action filings were at their highest level in 2002 and 2004, with fifty-eight and fifty-five filings respectively. Class action filings were at their lowest level in 2006 and 2008, with twenty-three and twenty-six filings respectively. CAFA took effect on February 18, 2005. Thus, the two highest years in the study preceded CAFA, the two lowest years in the study came after CAFA, and the drop-off from the highest years to the lowest years was over fifty percent. 
Figure 1: Oklahoma State-Court Class-Action Filings by Year

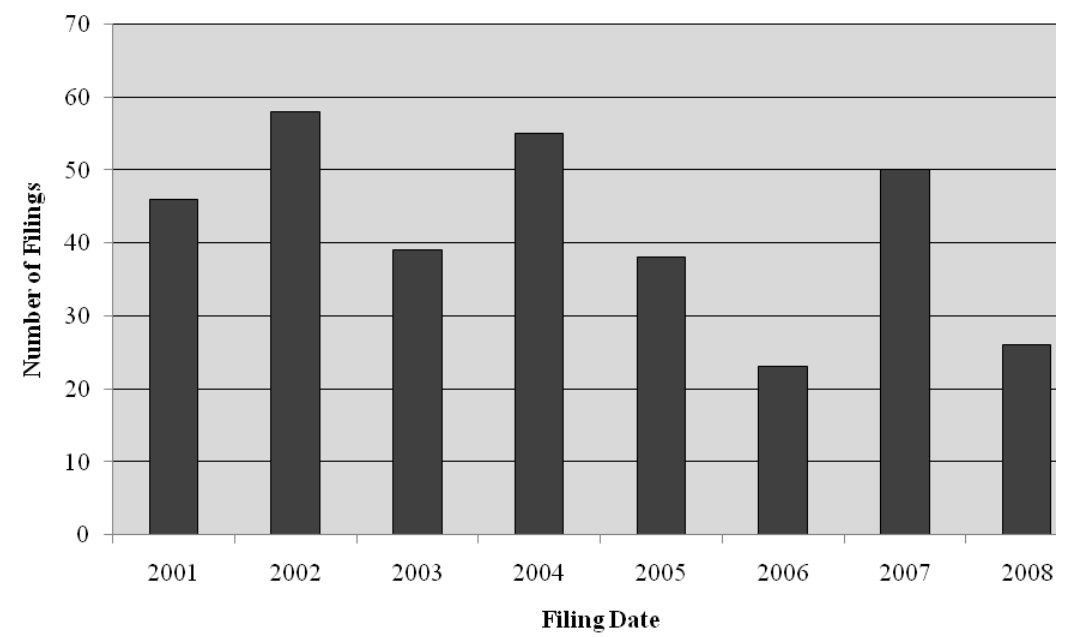

Class action filings did experience a spike of fifty filings in 2007. Further analysis showed that thirty-two of those cases were filed in Oklahoma County. Of those, twenty-eight were "unwanted fax" cases. ${ }^{80}$ These cases certainly deserve to be counted; they were validly filed and some of them resulted in substantial recoveries for the class. Nonetheless, the spike in filings traces to a specific and nonrecurring influx of filings - nearly all of them filed in clusters by the same lawyer for the same named plaintiffs - rather than a general surge in class action activity.

Figure 2 presents the same Oklahoma state-court filing data but breaks it out into six-month periods. The six-month data more clearly locate the timing of the drop-off in class action activity. Up to and including the first half of 2005 (which includes CAFA's effective date), class action filings averaged just under twenty-five per six-month period, with a median of twenty-three. Beginning with the second half of 2005, class action filings averaged sixteen per six-month period, with a median of thirteen. Thus, average filings dropped by $36 \%$, and the median dropped by $43 \%$. If we disregard the first half of 2007 (which experienced the "unwanted fax" case spike), class action filings post-

80. Congress provides a private right of action for the receipt of unsolicited facsimile advertisements. Telephone Consumer Protection Act, 47 U.S.C. $§ 227(b)(3)$ (2005), amended by Junk Fax Protection Act, Pub. L. No. 109-21, 119 Stat. 359 (2005). Though the cause of action is federal, jurisdiction lies in the state courts, "if otherwise permitted by the laws or rules of court of a State." Id. 
CAFA averaged thirteen per six-month period, with the median remaining at thirteen. That would translate to a $48 \%$ drop in the average filing rate and a $43 \%$ drop in the median filing rate.

Figure 2: Oklahoma State-Court Class-Action Filings by Six-Month Period

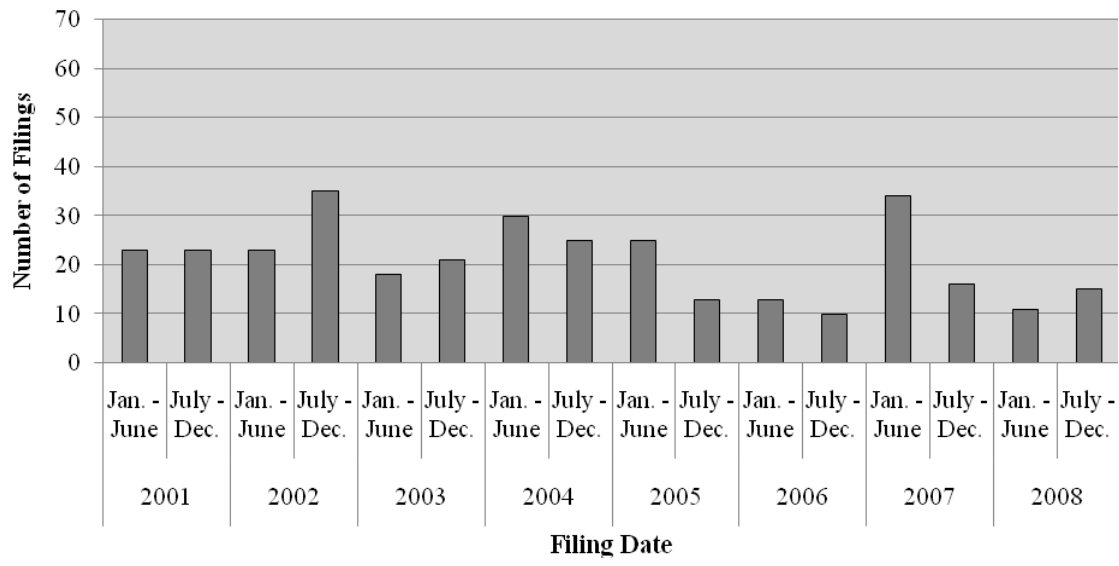

We can also see the impact of CAFA by looking more closely at the data from the first six months of 2005, when CAFA took effect. Table 1, below, shows class action filings during the full six-month period broken down into three periods: (1) pre-CAFA; (2) on February 18, the effective date of CAFA; and (3) post-CAFA. During the first forty-eight days of 2005 prior to CAFA's effective date, twelve class actions were filed. ${ }^{81}$ During the 132 days after CAFA's effective date, ten class actions were filed. Put another way, in the days leading up to CAFA, lawyers were filing class actions in Oklahoma at the rate of one every four days. Once CAFA took effect, the filing rate dropped to one every thirteen days. That figure is consistent with filing rates in the subsequent six-month periods. Using the median filing rate per six-month period (thirteen), lawyers were filing class actions in Oklahoma at the rate of one every fourteen days.

81. I have excluded the three class actions filed on February 18, 2005, because it is not clear to me whether to include them as pre-CAFA or post-CAFA cases. Though they are technically postCAFA, the data from Table 2 and my instincts persuade me that they most likely were botched attempts to beat CAFA's effective date. At any rate, even if we include those cases in the "postCAFA" figures, the filing rate still drops to one every ten days. 
Table 1: Oklahoma State-Court Class action Filings January 1 - June 30, 2005

\begin{tabular}{|c|c|}
\hline Period & $\mathrm{n}$ \\
\hline January 1 - February 17 & 12 \\
\hline $\begin{array}{c}\text { February 18 } \\
\text { (CAFA Effective Date) }\end{array}$ & 3 \\
\hline February 19 - June 30 & 10 \\
\hline
\end{tabular}

Table 2 takes an even closer view and shows class action filings by date during the month of February 2005. Together, Tables 1 and 2 seem to show a surge in class action filings leading up to CAFA's effective date, particularly if one views the cases filed on February 18 as miscalculated or belated attempts to file pre-CAFA.

Table 2: Oklahoma State-Court Class action Filings February 2005 Filing Dates

\begin{tabular}{|c|c|}
\hline Filing Date & $\mathrm{n}$ \\
\hline February 7 & 1 \\
\hline February 9 & 3 \\
\hline February 14 & 1 \\
\hline February 16 & 4 \\
\hline February 17 & 1 \\
\hline February 18 & 3 \\
\hline (CAFA Effective Date) & 1 \\
\hline February 24 & \\
\hline
\end{tabular}

These findings, so far, show rather clearly that class action filings in Oklahoma fell significantly after CAFA took effect. Standing alone, however, the drop in class action filings in Oklahoma does not prove the hypothesis being tested - namely, it does not prove that CAFA caused a shift of class action filings from state court to federal court. To know that, we must return to the federal-court data to see if there was a corresponding increase in federal-court filings. 
Figure 3 presents data on federal-court class action filings and removals in the federal districts in Oklahoma from July 2001 through June 2007. ${ }^{82}$ If the hypothesis of a direct CAFA shift from Oklahoma state court to the Oklahoma federal courts were true, we should expect to see a significant rise in the number of class actions filed in the Oklahoma federal courts post-CAFA. In fact, we find quite the opposite. Starting

Figure 3: Class-Action Filings and Removals in All

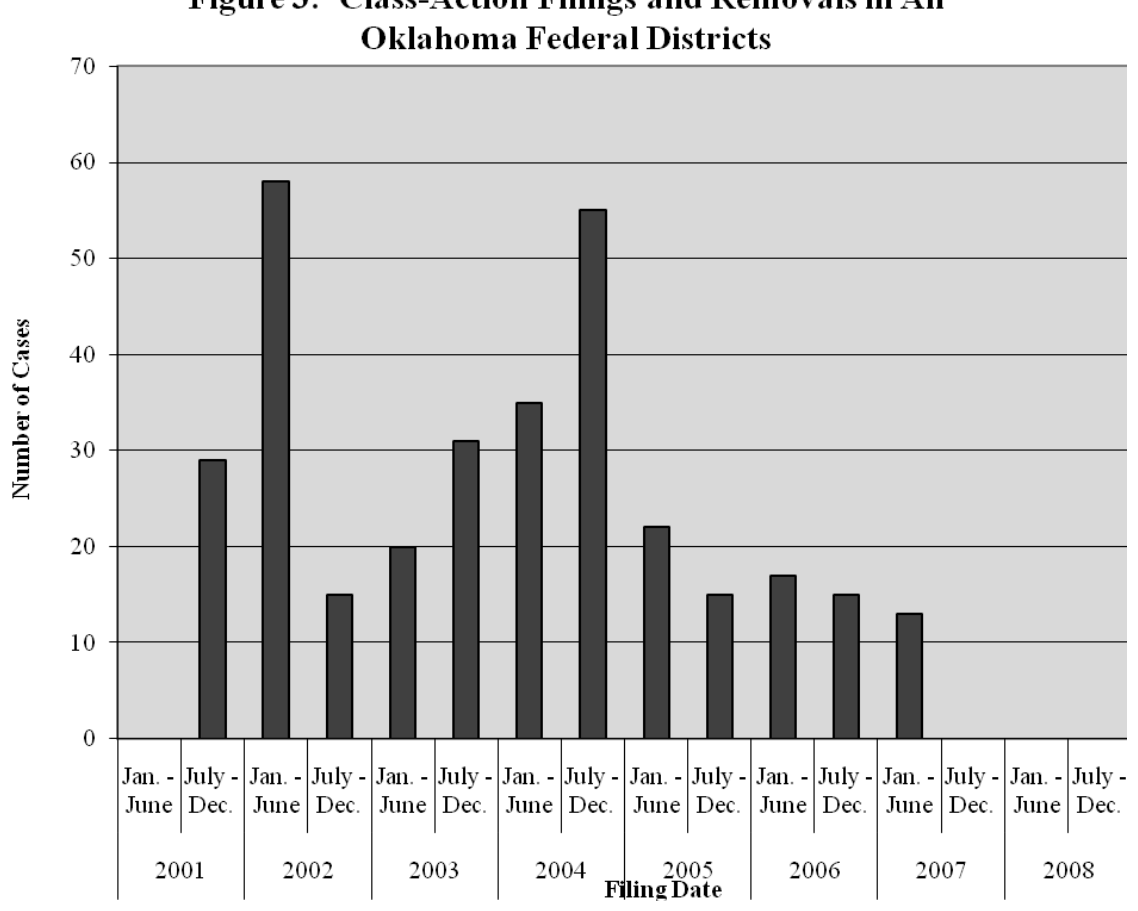

with the six-month period that includes CAFA's effective date, class action filings and removals in the Oklahoma federal courts experienced a steep decline.

Moreover, the decline was mostly attributable to a drop in original filings. Figure 4 provides a line graph showing original filings, removals, and remands in the Oklahoma federal districts from July 2001 through June 2007. Removal activity was always modest during this period, never exceeding twelve during any six-month period. Beginning with the six-month period starting July 1, 2005, it has been minimal,

82. Credit for this data goes to the FJC, which graciously provided me with access to its national data set so that I could compile filings data from the Oklahoma federal districts. Note that the FJC's study period concluded after June 2007. Thus, I do not have federal data to compare with the last three six-month periods of Oklahoma filing data. 
never exceeding three during any six-month period. What the line graph does show is that (1) there were two spikes in original filings with the most recent in the latter half of 2004 and (2) post-CAFA there was a decrease in both the number of original filings and the number of removals.

\section{Figure 4: Original Filings, Removals, and Remands in} all Oklahoma Federal Districts

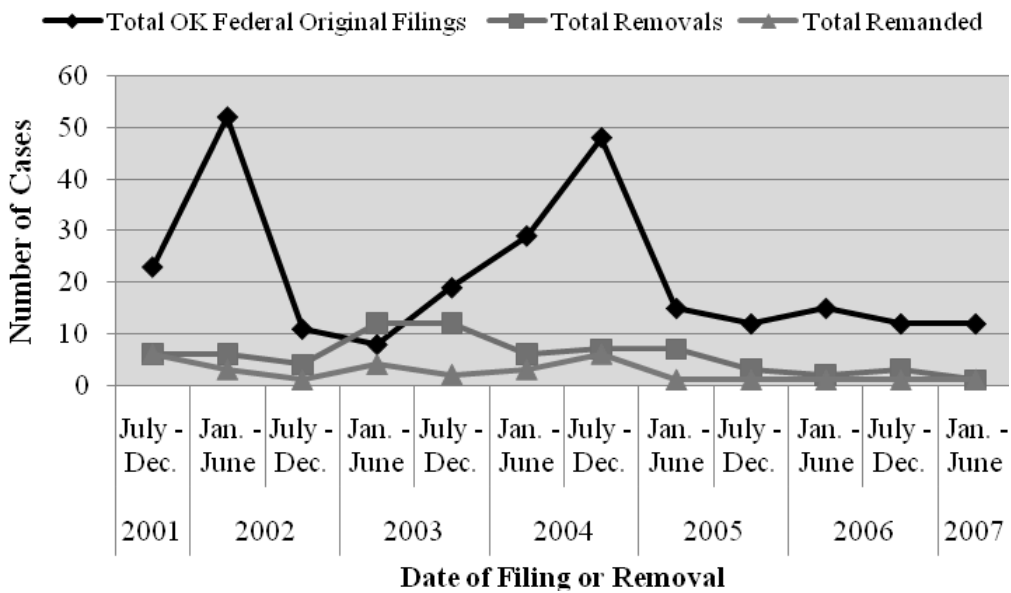

To complete the picture, Figure 5 presents a bar graph showing the total number of Oklahoma federal-court and Oklahoma state-court class actions filed during the respective study periods. ${ }^{83}$ If, say, CAFA were simply shifting state-law class actions from the courts of State $X$ to the federal courts located in State $X$, we would expect to see the total number of filings remain fairly constant; the difference would be a shift in where they were filed and/or an increase in the number of removals. Instead, with the exception of the first half of 2007, there appears to have been an across-the-board reduction in the number of class actions filed in Oklahoma. Thus, these data provide no support for the hypothesis that CAFA would shift class action activity from the state courts to the federal courts located in those states.

83. In this chart we counted only original filings to ensure that removed cases were not doublecounted. However, the chart does indicate the number of cases that were removed and not remanded in order to show what portion of the state-filed cases were ultimately resolved in federal court. 
Figure 5: Oklahoma State-Court and Federal-Court ClassAction Filings Combined

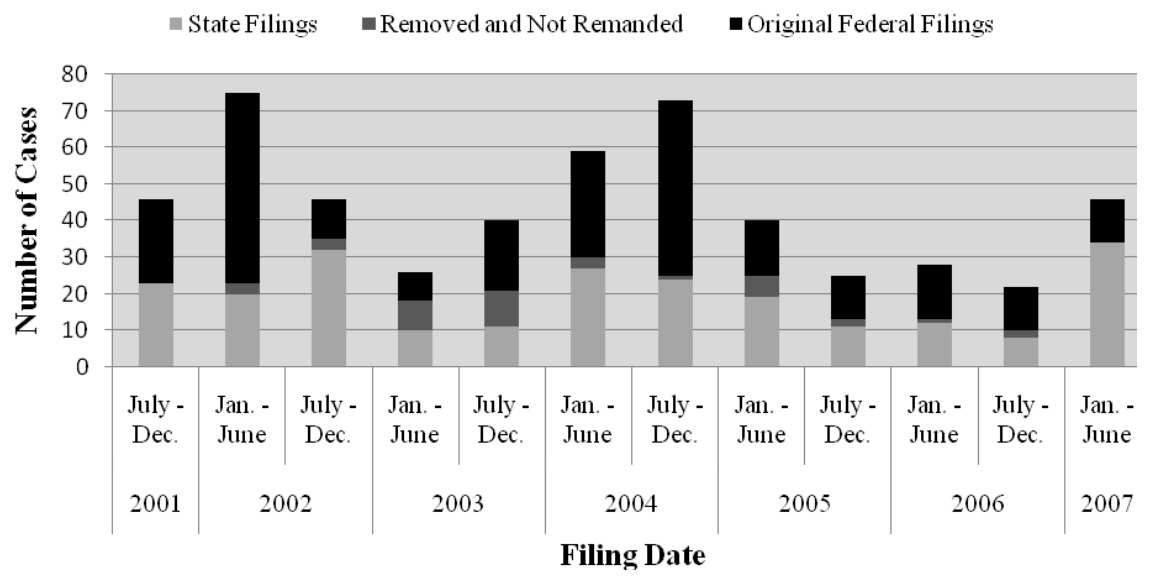

If we accept the premise that class action filings in Oklahoma at both the state and federal level have fallen since CAFA, what might explain that result? One possibility, of course, is that lawyers are simply filing fewer class actions. That is a very real possibility. Professor Erichson has greatly enriched our understanding of aggregate litigation by showing how lawyers have found nonclass means of litigating and settling mass disputes on a collective basis. ${ }^{84}$ In their contribution to this symposium, Tom Willging and Emery Lee present empirical support for the conclusion that lawyers are increasingly using nonclass settlements to resolve mass-tort litigation. ${ }^{85}$ Another possibility is that the reduction in state-court class action filings will prove to be temporary. There is much anecdotal evidence to suggest that plaintiffs' lawyers made anticipatory filings pre-CAFA in order to avoid its jurisdictional impact. At a limited level, the data in Tables 1 and 2 above support the notion that there was at least a mini-rush to file in advance of CAFA. My own discussions with plaintiffs' class action lawyers in Oklahoma tend to support that idea as well. In response to questions about whether CAFA has impacted their practices, more than one lawyer told me that CAFA had not yet been an issue for them because they were still "working off the inventory."

84. Erichson, supra note 11 , at 1625 .

85. Thomas E. Willging \& Emery G. Lee III, From Class Actions to Multidistrict Consolidations: Aggregate Mass-Tort Litigation after Ortiz, 58 U. KAN. L. REV. 775, 787-89, 793802 (2010). 
Another possible reason for the drop in class action activity in Oklahoma is that national class actions are still being filed, but in places other than Oklahoma. If that is the case, where are they being filed? The following paragraphs consider two possibilities: (1) that they are being filed in federal courts in places other than Oklahoma and (2) that they are being filed in other states.

Figure 6: Chart from FJC's Third Interim Report

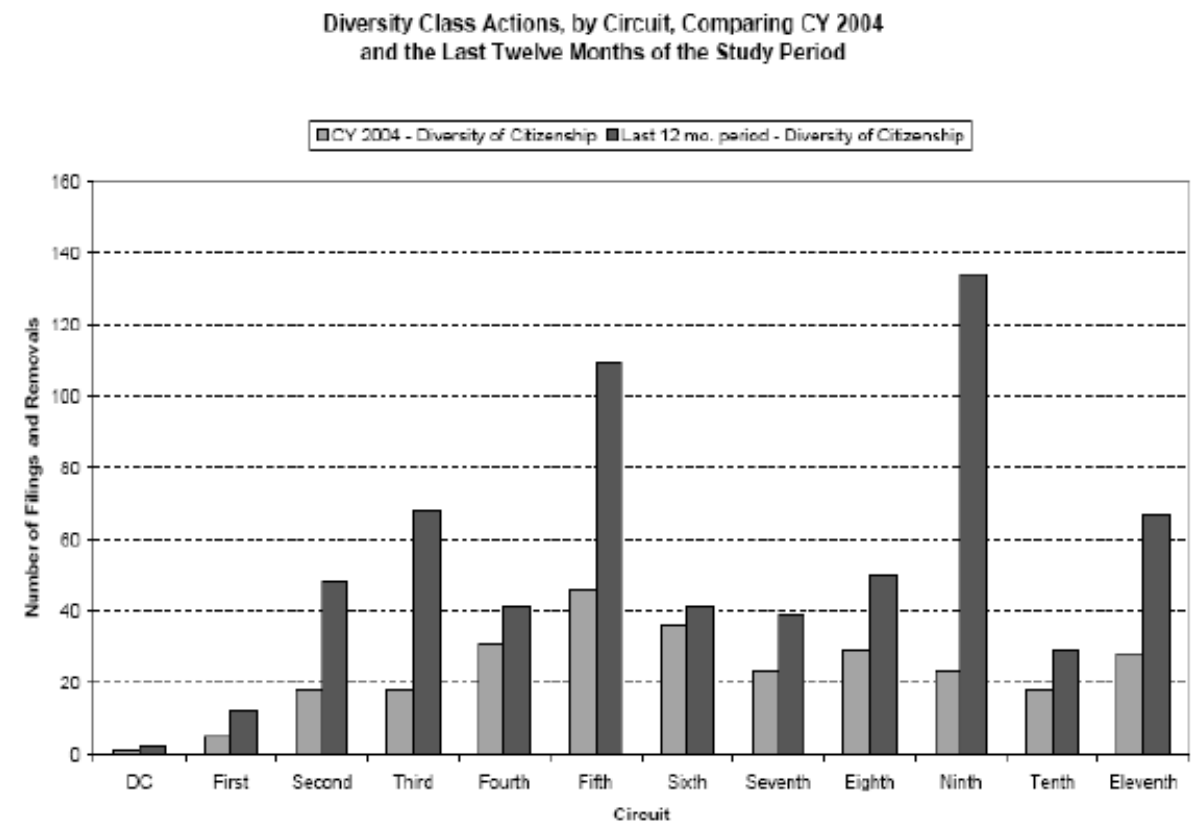

There is intriguing evidence to suggest that the horizontal forum shopping that used to take place on a state-to-state basis is now taking place on a federal-court-to-federal-court basis. Figure 6 is a chart prepared by the FJC. $^{86}$ As the chart shows, class action activity based on diversity-of-citizenship jurisdiction increased post-CAFA in every circuit. Those data are consistent with the hypothesis that CAFA would shift dockets from the state courts to the federal courts. However, the size of the increase varied greatly across the circuits. ${ }^{87}$ Certain circuits-

86. Thomas E. Willging \& EMery G. Lee III, The Impact of the Class Action Fairness ACT OF 2005 ON THE FEDERAL COURTS: THIRD INTERIM REPORT TO THE JUdiCIAL CONFERENCE ADVISORY COMMITTEE ON CIVIL RULES 18 (2007) http://www.fjc.gov/public/pdf.nsf/lookup /cafa0407.pdf/\$file/cafa0407.pdf; see also Lee \& Willging, supra note 3, at 1759 (chart reproduced and analyzed therein).

87. These variations existed at the district court level as well. LEE \& WILLGING, supra note 6, 
especially the Ninth, but also the Third, Fifth, and Eleventhexperienced dramatic increases in diversity class action filings after CAFA took effect. Other circuits - e.g., the Tenth Circuit - had much smaller increases. Moreover, most of the increase in the Tenth Circuit was attributable to removals rather than original filings. ${ }^{88}$

If plaintiffs are in fact "shopping the circuits," we ought not be surprised. ${ }^{89}$ By definition, national class actions reach across the country. The same liberal due-process standards that support personal jurisdiction in states across the country also support personal jurisdiction in federal districts across the country. ${ }^{90}$ Moreover, in the case of a defendant subject to personal jurisdiction in every state, venue conceivably could be available in every district in the country as well. ${ }^{91}$ Thus, a plaintiff choosing to file a national class action in federal court under CAFA is likely to have her choice of federal districts in which to file. Of course, the fact that CAFA jurisdiction is concurrent with statecourt jurisdiction means that plaintiffs remain free to forum shop the states. But savvy plaintiffs will recognize that defendants that are sued in a plaintiff-friendly state court will be sure to remove, and removal will be to the federal district in which the state court where the case was filed sits. $^{92}$ Thus, it would be perfectly logical for savvy plaintiffs to file in federal court in the first place so that they at least can control the choice of federal forum.

So, one way of reading the Oklahoma state-court and Oklahoma federal-court data is as a sign that plaintiff's lawyers with national class actions do not think that filing anywhere in Oklahoma offers the best prospects for success. At least until the November 1, 2009, class action reforms took effect, Oklahoma was viewed as having certification friendly class action standards. ${ }^{93}$ But a plaintiff filing a contested ${ }^{94}$ national class action in Oklahoma state court could fairly predict a quick removal to federal court under CAFA, with class certification then being

at $9-10$.

88. Lee \& Willging, supra note 3 , at 1761.

89. Erichson, supra note 11, at 1612-14; Lee \& Willging, supra note 3, at 1761-62 (but noting that not all of the data supports the federal forum-shopping hypothesis).

90. FED. R. CIV. P. 4(k)(1)(A) (generally aligning personal jurisdiction in federal court with personal jurisdiction in the state in which the federal court sits).

91. 28 U.S.C. § 1391(a) (2006) (venue lies in any district in which the defendant is subject to personal jurisdiction).

92. Id. § 1441(a).

93. See supra notes $21-29$ and accompanying text.

94. Plaintiffs' lawyers filing uncontested class actions-i.e., those in which the defendant has already agreed to a settlement - present much different forum-shopping dynamics and are discussed infra. See infra notes $105-07$ and accompanying text. 
subject to Tenth Circuit standards. So if Tenth Circuit class action practices are less advantageous to plaintiffs than those in other circuits, it would be perfectly rational for lawyers to bypass both the Oklahoma state courts and the Oklahoma federal courts. While I have not attempted to analyze the case law to determine where the Tenth Circuit might fall on a hierarchy of attractiveness to class action plaintiffs (and their lawyers), post-CAFA removal data supply an intriguing surrogate. Whereas original filings in the Tenth Circuit increased only slightly postCAFA, removals increased by nearly $200 \%{ }^{95}$ In contrast, several circuits often associated with more lenient certification practices - e.g., the Third Circuit and the Eleventh Circuit - saw a much larger postCAFA increase in original filings compared to removals. ${ }^{96}$ The fact that, compared to other circuits, the Tenth Circuit was much more attractive to defendants than to plaintiffs certainly supports the inference that Tenth Circuit class action practices favor defendants.

While the general idea that plaintiffs' class action lawyers would shop the circuits in terms of original filing makes a great deal of sense to me, the idea that plaintiffs' class action lawyers would flee from Oklahoma is puzzling to me in one aspect. Absent some overriding directive, a federal court sitting in diversity applies the choice-of-law rules of the state in which it sits. ${ }^{97}$ As noted earlier, Oklahoma has interpreted its version of the Restatement (Second) of Conflict of Laws as choosing the law of a single state - that of the defendant manufacturerto govern the claims of all class members in a national warranty class action. ${ }^{98}$ CAFA did not explicitly alter the choice-of-law rules governing state-law class actions. ${ }^{99}$ Thus, a federal court located in Oklahoma would still apply Oklahoma's choice-of-law scheme to a national statelaw class action originally filed in Oklahoma. Given the critical impact that choice of law has on predominance under Federal Rule 23(b)(3), ${ }^{100}$

\footnotetext{
95. See Lee \& Willging, supra note 3, at 1760 fig.7.

96. See id.

97. Klaxon Co. v. Stentor Elec. Mfg. Co., 313 U.S. 487, 496 (1941).

98. Ysbrand v. DaimlerChrysler Corp., 81 P.3d 618, 625-26 (Okla. 2003).

99. Silberman, supra note 32, at 2025. Some have argued that CAFA empowers federal judges to craft a federal common-law choice-of-law rule in CAFA cases. See, e.g., Samuel Issacharoff, Settled Expectations in a World of Unsettled Law: Choice of Law After the Class Action Fairness Act, 106 Colum. L. REV. 1839, 1869 (2006) (arguing that federal judges need not follow state choice-of-law rules in CAFA cases and should adopt a default rule of applying the law of the defendant's home state in cases involving national conduct). As of this writing, I am not aware of any federal cases that have taken that path.

100. See Steven S. Gensler, Federal Rules of Civil Procedure: Rules and COMMENTARY 366-67 (2009) (discussing role of choice of law in class certification); see also Linda J. Silberman, Choice of Law in National Class Actions: Should CAFA Make a Difference?, 14 Roger Williams U. L. ReV. 54, 57-59 (2009) (same).
} 
the availability of Oklahoma choice of law would, to me, make the Oklahoma federal courts attractive to national warranty cases even if Tenth Circuit certification standards might be considered more demanding in general. That being said, I have no reason to believe that the national plaintiffs' class action bar has not factored that into the forum-selection equation already, and they do appear to be voting "not Oklahoma" with their feet.

At this point, we cannot rule out a different explanation for the drop in class action activity in Oklahoma - that a portion of Oklahoma's class action docket has shifted to other state courts. On the surface, this may seem like an odd premise. After all, the whole point of CAFA was to counteract state-level forum shopping by opening up the federal courthouse doors, particularly for defendants wishing to remove. Yet while CAFA greatly undermined much of the incentive structure for state-level forum shopping, it did not make state-to-state differences wholly irrelevant, nor did it remove all incentive for filing in state court originally.

First, CAFA does not eliminate the incentive to file even contested national class actions in state courts when the state-court and the federalcourt class action practices are equally favorable. In that case, the defendant would have less (or no) incentive to remove, and the plaintiff would be happy with either the state forum or the federal forum in the event of removal. If such a state existed and if there were plaintiffs still wishing to proceed in a state forum, one might expect such plaintiffs to file their national state-law class actions in that state.

Does such a state exist? Though I have not attempted to try to identify state-federal court pairings that might meet those criteria, California may warrant a look in that regard. At the federal level, class action activity in the districts in the Ninth Circuit surged. Original filings increased by nearly $400 \%$, while removals increased by over $100 \% .^{101}$ In the Central District of California, original filings increased nearly $500 \%{ }^{102}$ But class action filings in the California state courts more or less held steady during that period. ${ }^{103}$ These data certainly suggest that class action plaintiffs are forum shopping the federal courts and liking what they see in the Ninth Circuit and the federal districts in California. But it also appears that class action plaintiffs continue to like

101. LEE \& WILLGING, supra note 6, at 8-9.

102. Id. at 9 .

103. See Hehman, supra note 12, at 3-4. While class action filings dropped from 833 in 2004 to 751 in 2005 , the 2005 filing rate was still the second highest in the study period, consistent with a six-year trend of annual twelve percent growth. Id. 
what they see in California state court as well. In its study, the California OCR has collected data on the size of the class and the class definition. ${ }^{104}$ Perhaps that data will shed light on (1) whether plaintiffs are filing national class actions in California state court post-CAFA and (2) whether any of those cases are being left in state court by virtue of the defendants foregoing removal.

Second, state-court class action practices also continue to matter very much in cases where the class lawyers and the defendant have reached a settlement and are looking for a state court that will certify the settlement class and approve the settlement. In this type of scenario, the class action practices of the federal circuit are irrelevant since neither the plaintiff nor the defendant intend to invoke federal jurisdiction. ${ }^{105}$ From this perspective, though, there is little to account for the drop in Oklahoma state-court filings during the study period. ${ }^{106}$ As the certification and resulting coupon settlement in Grider v. Compaq show, Oklahoma judges have signed off on class settlements that might raise eyebrows or be subject to restrictions elsewhere. ${ }^{107}$ I will return to this topic later in the discussion of the data on filing rates of litigation classes versus filing rates of settlement classes.

Finally, the drop in Oklahoma state-court filings may simply be the natural byproduct of the narrowness of CAFA's carve-outs. As discussed earlier, both of CAFA's mandatory carve-outs require a predominantly in-state class and the presence of a qualifying in-state defendant. ${ }^{108}$ Speaking generally, the only time defendants are barred from removing is when they are sued in their home states by a class of home-state citizens. When a defendant is not a citizen of the state in which the suit is filed, it will be able to remove even if every class member is from that state and all of the relevant activity occurred in that state. The bottom line is that the CAFA in-state carve-outs require local plaintiffs and local defendants. Viewed pragmatically, CAFA links the size of a state's docket of nonremovable class actions to the size of that

\footnotetext{
104. Id. at 1.

105. See supra notes $65-66$ and accompanying text.

106. It remains to be seen how the recent Oklahoma class action reforms will impact certification and settlement approval practices in the Oklahoma state courts.

107. Under CAFA, for example, percentage-of-fund attorney's fees must be based on the value of coupons redeemed rather than the face value. See 28 U.S.C. $§ 1712$ (a) (2006). In Texas-and now in Oklahoma-lawyers who secure class compensation in the form of coupons or other discounts are to be paid in kind. TeX. R. CIV. P. 42(i)(2); OKLA. STAT. tit. $12 \S 2023(\mathrm{G})(4)(\mathrm{f})$.

108. See supra notes 56-64 and accompanying text. The term "qualifying" in-state defendant means either a "significant" defendant under $\S 1332(\mathrm{~d})(4)(\mathrm{A})$ or a "primary" defendant under $\S 1332(d)(4)(B) .28$ U.S.C. $§ 1332(d)(4)(A)(i)(I I)(a a), 1332(d)(4)(B)(2006)$.
} 
state's corporate base. In order to bring a viable in-state class action, you need a local defendant worth suing on a class-wide basis.

If that premise is true, we would expect in-state class action activity to remain the strongest in the large states with large numbers of corporate defendants and to decrease in the smaller states with fewer class action targets. Here too, a comparison of the post-CAFA experiences of California and Oklahoma may be telling. As detailed earlier, California is the largest state in the union and has one of the largest economies in the nation. ${ }^{109}$ It is also home to ninety-eight of the Fortune 1000 companies. ${ }^{110}$ In contrast, Oklahoma is a much smaller state with a much smaller economy. ${ }^{111}$ Moreover, it is home to just six of the Fortune 1000 companies and zero that rank in the top $100 .{ }^{112}$ Is it really any surprise that post-CAFA class action activity remains strong in California but is in decline in Oklahoma?

Viewed from this angle, the future of state-court class actions starts to look like a demographics and math problem. Post-CAFA, what contested class actions would make economic sense to bring in Oklahoma state court? There are relatively few large local corporate targets. And while the class size could conceivably run into the millions, it necessarily would have to exclude ninety-eight percent of the U.S. population. Some types of Oklahoma state-court class actions will continue to make economic sense. In particular, I would expect lawyers to continue to file oil-and-gas royalty class actions in Oklahoma against in-state energy companies. But in California and other states with either large populations or large corporate bases, it seems likely that a much wider range of state-court class actions will continue to make economic sense. ${ }^{113}$

109. See supra notes $14-15$ and accompanying text.

110. Fortune 500 2009: States: California Companies, http://money.cnn.com/magazines/fortune/ fortune 500/2009/states/CA.html (last visited Feb. 7, 2009).

111. See supra notes $17-20$ and accompanying text.

112. Fortune 500 2009: States: Oklahoma Companies, http://money.cnn.com/magazines /fortune/fortune500/2009/states/OK.html (last visited Feb. 7, 2009).

113. I do not want to overstate this hypothesis. Many factors will influence the robustness of instate class action practice, including the availability of state-specific causes of action. For example, the OCR study notes an increase in the number of class actions brought in California under California's labor code and consumer-protection laws. See HeHMAN, supra note 12, at 7-10. That being said, the size of a state's workforce and the number of large defendants will still have an impact on the number of viable class actions that might be brought under those laws. 


\section{Certification and Outcomes of Certified Cases}

In this section of the Article, I present preliminary findings on certification rates in Oklahoma state court and the outcomes of certified cases. The data here are necessarily interim data as many of the cases are still pending and many of them have pending motions for certification or settlement approval. ${ }^{114}$

Table 3 presents data on the frequency of certification motions in cases identified as having any class action activity. Overall, certification motions were filed in fewer than $45 \%$ of those cases. If only pre-CAFA cases are considered, however, the number rises to slightly more than $52 \%$, compared to approximately $33 \%$ in the post-CAFA cases. At this point, it is not possible to tell whether this difference will persist or whether the post-CAFA figure will rise as more certification motions are filed in those more recently filed cases.

Table 3: Frequency of Motions to Certify

\begin{tabular}{|c|c|c|c|}
\hline & $\begin{array}{c}\text { Pre-CAFA } \\
(\mathrm{N}=210)\end{array}$ & $\begin{array}{c}\text { Post-CAFA } \\
(\mathrm{N}=125)\end{array}$ & $\begin{array}{c}\text { Total } \\
(\mathrm{N}=335)\end{array}$ \\
\hline $\begin{array}{c}\text { Certification } \\
\text { Sought }\end{array}$ & $110(52.4 \%)$ & $41(32.8 \%)$ & $151(44.8 \%)$ \\
\hline
\end{tabular}

The fact that motions to certify were filed in only about half of the Oklahoma class action filings in our study should not come as a surprise. In their contribution to this symposium, Willging and Lee analyze data regarding the frequency of class certification motions from four different studies. ${ }^{115}$ These studies found certification motion rates of $24 \%, 43 \%$, $51 \%$, and $70 \% .^{116}$ Because these studies were conducted at different times using different populations and different methods, the fact that they resulted in a rather wide range of percentages is less important than the more general finding that, in a substantial portion of cases with class

114. There are two relevant screening dates for this data. In April 2009, we screened the full data set to identify the cases in which motions to certify had been filed. At the same time, we coded the cases to determine the outcomes of those motions and to identify the case outcomes in cases where class certification was granted. In October 2009, we revisited the population of cases where a motion to certify was filed in order to update the data on the outcomes of those motions and case outcomes. We did not rescreen the full data set to determine whether any new motions to certify had been filed during the period between April and October 2009. Thus, the findings presented here set forth data current through October 2009 on the cases in which a motion to certify had been filed as of April 2009.

115. Willging \& Lee, supra note 85 , at $787-88$.

116. Id. at 789 . 
allegations, no motion to certify the alleged class is ever filed. ${ }^{117}$ Most recently, the Second Interim Report from the California OCR study found that there was no certification activity in $73 \%$ of the cases filed as class actions. ${ }^{118}$ Some of the lack of certification activity likely is attributable to the rigorous case management practices employed as part of California's Complex Civil Litigation Program. ${ }^{119}$ Nonetheless, the California data mirrors the federal data and the Oklahoma data in showing "a significant gap between cases that are simply filed as class actions and those that are ultimately litigated as class actions."120

In those cases where certification is sought, the plaintiffs look to be doing fairly well. Table 4 presents data on the fate of cases after the plaintiff moves for certification. By far the most common outcome in Oklahoma was that certification would be granted. For all cases in this study where certification was sought, the court granted certification approximately $53 \%$ of the time. In pre-CAFA cases, the percentage was over $58 \%{ }^{121}$ In comparison, denials of certification were relatively uncommon. Overall, the court denied certification in just seventeen cases $(11 \%)$. To put this in perspective, it was more likely that the plaintiff would voluntarily dismiss for reasons not related to class status (eighteen cases or $12 \%$ ) than it was that the court would outright deny the request for certification.

117. Id.

118. Hilary Hehman, Class Certification in CALIFORNia: SECOND INTERIM Report From THE StUdy OF CALIFORNia Class ACTION Litigation 5 (2009), http://www.courtinfo.ca.gov/ reference/documents/classaction-certification.pdf.

119. Id. at 7-8.

120. Id. at 8 .

121. The percentage of certification grants in post-CAFA cases was $41 \%$. However, the motion was still pending in $17 \%$ of the cases. Thus, the percentage of grants is almost certain to increase. If half of the pending cases lead to grants, the post-CAFA certification rate will be roughly $48 \%$. 
Table 4: Outcomes When Class Certification Sought

\begin{tabular}{|c|c|c|c|}
\hline Certification Granted & $\begin{array}{c}\text { Pre-CAFA } \\
(\mathrm{N}=109)\end{array}$ & $\begin{array}{c}\text { Post-CAFA } \\
(\mathrm{N}=41)\end{array}$ & $\begin{array}{c}\text { Total } \\
(\mathrm{N}=150)\end{array}$ \\
\hline Certification Denied & $12^{\mathrm{a}}$ & 17 & 80 \\
\hline Still Pending & 3 & 7 & 17 \\
\hline $\begin{array}{c}\text { Voluntary Dismissal } \\
\text { Not Class-Related }\end{array}$ & 15 & 3 & 18 \\
\hline $\begin{array}{c}\text { Defense Win } \\
\text { Precertification }\end{array}$ & 3 & 4 & 7 \\
\hline $\begin{array}{c}\text { Class Treatment } \\
\text { Abandoned }\end{array}$ & 2 & 3 & 5 \\
\hline $\begin{array}{c}\text { Dismissed For Failure } \\
\text { to Prosecute }\end{array}$ & 2 & 0 & 2 \\
\hline Other & 9 & 2 & 11 \\
\hline
\end{tabular}

${ }^{\mathrm{a}}$ This category includes one case in which the class allegations were stricken by the court.

These Oklahoma findings are generally consistent with findings from Phase Two of the FJC study. In the federal study sample, the court granted thirty of seventy $(43 \%)$ motions to certify. ${ }^{122}$ The principal difference is found in the denial rate: federal judges denied the motion to certify in eighteen of seventy $(26 \%)$ cases. ${ }^{123}$ Roughly stated, federal judges seem only slightly less inclined to grant certification but considerably more inclined to enter an order formally denying it. The California data are quite similar. The grant rate in California was 46\%; the denial rate was $19 \% .{ }^{124}$

When certification is granted, there is a very high likelihood that the case will result in a settlement. Table 5 presents data on the outcomes of cases in which the trial court granted a motion for class certification. Out of the eighty cases that were class certified, a total of fifty-nine (74\%) resulted in a settlement, with twelve still pending. Only nine of the eighty certified cases have concluded with something other than a settlement. Just two were tried, and one of those settled after trial. Only one was decertified. Thus, if form holds, it is likely that most of the pending cases will also terminate in a settlement.

122. See LEE \& WiLLGING, supra note 67 , at 11 .

123. Id.

124. HEHMAN, supra note 118 , at 9. 
Table 5: Case Outcomes in Certified Class Actions

\begin{tabular}{|c|c|c|c|}
\hline Outcome & $\begin{array}{c}\text { Pre-CAFA } \\
(\mathrm{N}=63)\end{array}$ & $\begin{array}{c}\text { Post-CAFA } \\
(\mathrm{N}=17)\end{array}$ & $\begin{array}{l}\text { All Cases } \\
(\mathrm{N}=80)\end{array}$ \\
\hline $\begin{array}{c}\text { Certified for Litigation, } \\
\text { Then Settled }\end{array}$ & 21 & 3 & 24 \\
\hline $\begin{array}{l}\text { Certified for Settlement } \\
\text { and Settled }\end{array}$ & 28 & 7 & 35 \\
\hline Still Pending & 8 & 4 & 12 \\
\hline Decertified & 1 & 0 & 1 \\
\hline Reversed & 2 & 0 & 2 \\
\hline Defense Motion Win & 1 & 0 & 1 \\
\hline Plaintiff Motion Win & $1^{\mathrm{a}}$ & 0 & 1 \\
\hline Tried & $1^{\mathrm{b}}$ & 1 & 2 \\
\hline $\begin{array}{l}\text { Dismissed for Lack of } \\
\text { Prosecution }\end{array}$ & 0 & 2 & 2 \\
\hline
\end{tabular}

The finding that most certified class actions in Oklahoma settle should come as no surprise. Early federal-court empirical work found that most certified class actions settle. ${ }^{125}$ In the FJC's preliminary report on Phase Two of its CAFA study, it reported that every certified class action in the population of cases had terminated in a settlement. ${ }^{126}$ The California OCR study found a settlement rate of $89 \%$ in certified class actions. $^{127}$

One important question posed earlier is whether CAFA might have a disparate impact on contested "litigation classes" as compared to settlement classes. In a contested class action, the defendant will have an incentive to remove from a state with lax certification practices. But in a settlement class, both sides would have an incentive to forego CAFA jurisdiction and seek class certification and settlement approval in whatever state court (with jurisdiction) would present the most favorable combination of certification and settlement approval practices. To put it

125. See Thomas E. Willging et al., An Empirical Analysis of Rule 23 to Address the Rulemaking Challenges, 71 N.Y.U. L. REV. 74, 180 (1996) (finding approved certified class settlements in 100\% of cases in the Southern District of Florida, $88 \%$ of cases in the Northern District of California, $71 \%$ of cases in the Northern District of Illinois, and $62 \%$ of cases in the Eastern District of Pennsylvania during a two-year period).

126. LEE \& WILLGING, supra note 67, at 10-15.

127. See HEHMAN, supra note 118, at 23. 
more concretely, if lawyers continued to think that Oklahoma state courts were good places to get settlement classes certified and approved, then there would be no reason to expect CAFA to negatively impact those cases and filing rates of settlement classes should stay constant pre- and post-CAFA. On the other hand, we might expect CAFA to reduce the number of contested class actions in Oklahoma under the view that plaintiffs would be deterred from filing them knowing that defendants would be likely to remove them to federal court.

Based on one measure, settlement-class activity would appear to be holding steady in Oklahoma. As shown in Table 6, pre-CAFA, 46\% of settled class actions had been filed as settlement classes as opposed to contested "litigation classes." Post-CAFA, that figure was only slightly higher at $47 \%$. If it holds, ${ }^{128}$ these data would stand in contrast with a long-term trend in federal court in which the ratio of settlement classes to litigation classes has been increasing. ${ }^{129}$

Table 6: Nature of Certification

\begin{tabular}{|c|c|c|c|}
\hline & $\begin{array}{c}\text { Pre-CAFA } \\
(\mathrm{N}=63)\end{array}$ & $\begin{array}{c}\text { Post-CAFA } \\
(\mathrm{N}=17)\end{array}$ & $\begin{array}{c}\text { Total } \\
(\mathrm{N}=80)\end{array}$ \\
\hline $\begin{array}{c}\text { Certified for } \\
\text { Litigation }\end{array}$ & $34(54 \%)$ & $9(53 \%)$ & $43(53.8 \%)$ \\
\hline $\begin{array}{c}\text { Certified for } \\
\text { Settlement }\end{array}$ & $29(46 \%)$ & $8(47 \%)$ & $37(46.2 \%)$ \\
\hline
\end{tabular}

In absolute terms, though, settlement-class activity in Oklahoma would appear to be falling drastically. From January 1, 2001, to February 17, 2005, plaintiffs filed twenty-nine cases in which a settlement class was eventually certified. That calculates to a rate of one every fifty-two days. From February 18, 2005 (CAFA's effective date) to December 31, 2008, plaintiffs filed eight cases in which a settlement class was eventually certified, resulting in a rate of one every 177 days. Viewed from this perspective, it does not appear that lawyers are seeking out the Oklahoma state courts as a place to tee up post-CAFA settlement classes for class certification and settlement approval.

128. There are four post-CAFA certification motions still pending in Oklahoma. One is for a settlement class; the other three are for litigation classes. If all four are granted, then the percentage of classes filed as settlement classes will actually drop, to $42.8 \%$.

129. See Willging \& Lee, supra note 85 , at 791-92. 


\section{CONCLUSION}

During the past decade, Oklahoma gained a reputation as a state with a favorable class action environment. A combination of lenient certification standards, favorable choice-of-law rules, and generous settlement-approval practices made Oklahoma an emerging destination for forum-shopping class action lawyers. In short, Oklahoma was one of the states squarely in CAFA's cross hairs. Since CAFA took effect, class action filings in Oklahoma have decreased significantly, suggesting that, at least in Oklahoma, CAFA has had its intended impact. At the same time, though, class action filings in the Oklahoma federal courts have also decreased significantly. National federal-court data collected by the FJC show that, while diversity class actions increased post-CAFA, the increase has been much larger in some federal courts than it has been in others. Taken together, the Oklahoma and federal-court data suggest that the plaintiffs who used to forum shop their nationwide state-law class actions at the state level now may be forum shopping them at the federal level instead. 